\title{
PERBANDINGAN SIKAP DAN PENERIMAAN PENGGUNA LAYANAN DOMPET DIGITAL DI INDONESIA
}

\author{
Anggraeni Dias Saputri ${ }^{1)}$, Ahmad Raf'ie Pratama ${ }^{2)}$ \\ ${ }^{1}$ Magister Informatika, Universitas Islam Indonesia, Sleman, Daerah Istimewa Yogyakarta \\ email: anggraeni.saputri@sudents.uii.ac.id
}

\begin{abstract}
Abstrak
Di Indonesia, jenis e-payment yang umum diadopsi adalah dompet digital. Dompet digital telah menjadi bagian dari kehidupan sehari-hari masyarakat Indonesia. Meskipun demikian, tidak sedikit pula masyarakat Indonesia yang belum menggunakan fasilitas ini, penerimaan dompet digital di Indonesia masih belum sepenuhnya merata. Tidak sedikit penelitian yang membahas mengenai dompet digital, namun terbatas pada penelitian presepsi penerimaan tanpa berfokus pada variabelvariabel lain. Maka dari itu penelitian ini dilakukan untuk memberikan gambaran perbandingan atau perbedaan sikap dari pengguna layanan dompet digital di Indonesia. Data yang diperoleh dianalisis secara kuantitatif dengan teknik analisis Manova. Temuan penelitian ini menunjukkan relatif tidak ada perbedaan-perbedaan kecuali pada dua hal, yaitu pada faktor pengaruh sosial di mana perempuan melaporkan nilai yang lebih tinggi dibandingkan laki-laki. dan pada persepsi risiko yang justru sebaliknya, bahwa laki-laki melaporkan nilai yang lebih tinggi daripada perempuan. Adanya penelitian ini dapat melengkapi dan memperkaya literatur di bidang teknologi finansial dan memberikan gambaran perbandingan atau perbedaan sikap dari pengguna layanan dompet digital di Indonesia. Selain itu, pengetahuan dari penelitian ini tidak hanya bermanfaat bagi penyedia layanan dompet digital, namun secara luas bagi industri teknologi finasial.
\end{abstract}

Keywords: sistem informasi, dompet digital, Indonesia

\begin{abstract}
In Indonesia, the most commonly adopted electronic payment is an e-wallet. E-wallets have become a part of everyday life for Indonesians. Even so, there are not a few Indonesians who have not used this facility, the acceptance of e-wallets in Indonesia is still uneven. There are not a few studies that discuss e-wallets, however limited to research on acceptance without depending on other variables. Therefore this research was conducted to provide an overview of the comparison or differences in the attitudes of e-wallet users in Indonesia. The data obtained were analyzed quantitatively with Manova analysis technique. The findings of this study indicate that there are relatively no differences outside of two things, specifically the social influence in which women report higher scores than men. and on the perception of risk which is quite the opposite, that it was men who reported higher scores that were women. This research can complement and enrich the literature in the field of financial technology and provide an overview of the comparison or differences in attitudes of digital wallet services in Indonesia. In addition, the knowledge from this research is not only beneficial for digital wallet service providers, but widely for the financial technology industry.
\end{abstract}

Keywords: system information, e-wallet, Indonesia 


\section{PENDAHULUAN}

Teknologi finansial terus berkembang secara massif tidak hanya dalam ruang lingkup nasional, namun hingga multinasional. Bahkan sejak Januari 2016, pemerintah mencanangkan program less cash society demi menghadapi persaingan multinasional Masyarakat Ekonomi ASEAN (MEA) [1]. Salah satu upaya untuk meyukseskan program tersebut adalah dengan meminimalisir penggunaan uang tunai dengan menggunakan alternatif lain yakni electronic payment. Electronic payment (e-payment) adalah platform yang dapat digunakan untuk melakukan transaksi pembayaran barang atau jasa yang dibeli melalui penggunaan internet atau perangkat elektronik lainnya [2]. Koponen [3] menjelaskan bahwa terdapat berbagai macam sistem pembayaran online yang telah dikembangkan dan sistem ini dapat diklasifikasikan kedalam sistem berbasis akun dan sistem berbasis mata uang elektronik. Sistem berbasis akun memungkinkan pengguna melakukan pembayaran melalui rekening bank pribadi mereka, sedangkan sistem berbasis mata uang elektronik hanya mengizinkan pembayaran jika penggunanya memiliki jumlah mata uang elektronik yang memadai. Sistem ini menawarkan sejumlah metode yang dikategorikan menjadi beberapa jenis, yakni kartu elektronik (kartu kredit, debit dan charge), dompet digital, uang tunai elektronik, cek digital, dan sistem pembayaran nirkabel [4].

Di Indonesia, jenis e-payment yang umum diadopsi adalah dompet digital [5]. Dompet digital bukanlah hal yang baru bagi sebagian besar masyarakat Indonesia yang telah melek teknologi. Ada banyak layanan dompet digital yang tersedia di Indonesia, lima yang terbesar antara lain
ShopeePay, OVO, Dana, GoPay dan LinkAja [6]. Dompet digital telah menjadi bagian dari kehidupan sehari-hari masyarakat Indonesia. Rata-rata dompet digital digunakan sekitar satu hingga dua kali dan mencapai volume pengisian saldo sebesar Rp. 140.663,- perminggunya [7]. Meskipun demikian, tidak sedikit pula masyarakat Indonesia yang belum menggunakan fasilitas ini, penerimaan dompet digital di Indonesia masih belum sepenuhnya merata [8].

Penelitian mengenai penerimaan dompet digital dengan case study Dana dilakukan oleh Raihan dan Rachmawati [9] dengan mengadopsi model UTAUT 2 dengan modifikasi variabel tambahan sehingga memiliki delapan variabel, yaitu variabel Continuance Intention, Effort Expectancy, Facilitating Condition, Habit, Hedonic Motivation, Performance Expectancy, Price Saving Orientation, Social Influence dan Trust. Selain menambahkan variabel eksternal, penelitian ini juga menambahkan dua faktor moderasi, yaitu umur dan jenis kelamin. Untuk menguji hipotesis, penelitian ini menggunakan SEM dan software statistik Smart PLS 3.2.8. Hasil penelitian ini menunjukkan bahwa terdapat empat dari delapan faktor dalam Model UTAUT 2 yang telah dimodifikasi berpengaruh secara signifikan terhadap intensi keberlanjutan adopsi Dana, variabel yang signifikan tersebut antara lain variabel Trust, variabel Hedonic Motivation, variabel Social Influence dan variabel Habit. Dalam hal faktor moderasi, umur memoderasi Habit terhadap Continuance Intention dan jenis kelamin memoderasi Social Influence terhadap Continuance Intention. Penelitian dengan fokus dompet digital tertentu juga dilakukan oleh Widiyanti [10]. Penilitian ini menganalisis jenis dompet digital OVO dan pengguna 
layanan yang berdomisili di Depok dengan metode analisis kuantitatif asosiatif. Hasil dari penelitian ini mengemukakan bahwa penerimaan dompet digital OVO dipengaruhi oleh faktor kemudahan, kemanfaatan dan promosi. Penelitian mengenai penerimaan dompet digital lebih luas dilakukan oleh Angelina [5], namun masih dengan fokus wilayah tertentu yakni terbatas pada pulau Jawa. Dengan model UTAUT yang dimodifikasi, penelitian ini berhasil menguji penerimaan pengguna dompet digital di Pulau Jawa dipengaruhi oleh Performance Expectancy, Effort Expectancy, Social Influence, Perceived Security, Hedonic Motivation dan Relative Advantage.

Berbeda fokus dengan beberapa penelitian sebelumnya, penelitian yang dilakukan oleh Saputri dan Pratama [11] mengidentifikasi tentang karakteristik pengguna layanan dompet digital di Indonesia, data yang didapat melalui survey secara online dianalisis dengan model Logistic Regression. Penelitian ini mengeksplorasi tiga layanan dompet elektronik teratas di Indonesia yaitu, GoPay, OVO, dan DANA. Penelitian ini menemukan bahwa setiap layanan dompet digital yang ada memiliki karakteristik pengguna yang berbeda. Layanan dompet digital GoPay dan OVO banyak digunakan oleh individu dengan penghasilan menengah hingga atas, sedangkan layanan dompet digital Dana lebih diminati oleh kelas ekonomi menengah hingga bawah. Selain itu, layanan dompet digital Dana banyak digunakan oleh usia muda dan lebih diminati oleh pengguna laki-laki dibandingkan dengan perempuan.

Tidak sedikit penelitian yang membahas mengenai dompet digital, namun terbatas pada penelitian presepsi penerimaan tanpa berfokus pada variabel- variabel lain seperti kepercayaan, ekspektasi, karakteristik pembayaran elektronik hingga karakteristik penggunanya [12]. Sementara itu, penelitian mengenai variabel lain penting untuk dilakukan untuk menambah literatur dan wawasan yang tidak hanya bermanfaat bagi penyedia layanan dompet digital, namun secara luas bagi industri teknologi finasial. Maka dari itu penelitian ini dilakukan untuk dapat melengkapi dan memperkaya literatur di bidang teknologi finansial dan memberikan gambaran perbandingan atau perbedaan sikap dari pengguna layanan dompet digital di Indonesia.

\section{METODE PENELITIAN}

Penelitian ini dimulai dengan pemilihan topik permasalahan yang ingin dibahas, yaitu mengenai perbandingan sikap dan penerimaan pengguna layanan dompet digital di Indonesia. Layanan dompet digital yang dipilih pada penelitian yaitu GoPay, OVO, Dana, LinkAja dan ShopeePay sebagai layanan dompet digital di Indonesia yang terbesar untuk saat ini [6]. Setelah topik yang dipilih telah matang, langkah selanjutnya yaitu melakukan kajian literatur untuk memperluas wawasan dan pengetahuan. Selain itu, kajian literatur juga digunakan sebagai referensi dalam menentukan desain penelitian yang dibuat. Setelah desain penelitian telah siap, hal yang selanjutnya dilakukan yakni mengumpulan data yang akan diolah, dianalisis dan diinterpretasikan sebagai data primer dalam penelitian ini. Langkah berikutnya yaitu dengan mengemukakan penemuan sebagai hasil akhir dari penelitian yang dilakukan.

\section{Prosedur Pengumpulan Data}

Data primer yang diperoleh melalui pengisian kuesioner online secara mandiri akan dianalisis secara kuantitatif menggunakan statistik pada perangkat 
lunak R. Pengumpulan data dilakukan sejak Maret hingga Agustus 2020 melalui Google Forms, hingga terkumpul sebanyak 402 responden berpartisipasi dalam penelitian ini.

Kriteria responden dari penelitian ini yaitu bertempat tinggal di wilayah Indonesia dan berusia minimal 17 tahun serta pernah menggunakan layanan dompet digital setidaknya satu kali. Penelitian ini hanya melibatkan responden yang menggunakan layanan dompet digital GoPay, OVO, Dana, LinkAja dan ShopeePay. Responden diminta untuk mengisi informasi umum berupa usia dan jenis kelamin. Selain itu, responden juga menjawab beberapa pertanyaan terkait layanan dompet digital yang digunakannya. Pada penelitian ini, terdapat 10 faktor yang diteliti, yaitu faktor kegunaan (4 pertanyaan), faktor kemudahan (3 pertanyaan), faktor finansial (3 pertanyaan), faktor fasilitas penunjang (3 pertanyaan), faktor pengaruh sosial (4 pertanyaan), faktor keamanan (3 pertanyaan), faktor risiko (4 pertanyaan), faktor kesenangan (4 pertanyaan), faktor perilaku atau sikap pengguna (3 pertanyaan), dan faktor niat dari pengguna layanan dompet digital (3 pertanyaan). Setiap pertanyaan diberikan nilai menggunakan skala likert, yakni nilai 1 untuk Sangat Tidak Setuju, 2 untuk
Tidak Setuju, 3 untuk Netral, 4 untuk Setuju dan nilai 5 untuk Sangat Setuju.

\section{Metode Analisis}

Data yang diperoleh dibersihkan dan disortir sehingga hanya tersisa data yang tersisa merupakan data yang layak untuk diproses pada langkah selanjutnya. Data yang telah bersih tersebut kemudian dianalisis secara kuantitatif menggunakan statistik pada perangkat lunak $\mathrm{R}$ ver.3.6.2. Metode analisis data untuk mengukur pengaruh independent variables terhadap dependent variables yang berskala data kuantitatif, maka penelitian ini menggunakan teknik analisis Manova (Multiple Analysis of Variance) [13].

Metode Manova dipilih sebagai metode untuk menganalisis dan membandingkan sikap dan penerimaan pengguna layanan dompet digital di Indonesia. Dalam proses Manova yang dilakukan untuk membandingkan sikap dan penerimaan pengguna layanan dompet digital, data responden berupa jenis dompet digital yang paling sering digunakan, usia serta jenis kelamin digunakan sebagai independent variables. Sedangkan untuk dependent variables menggunakan hasil penilaian bulir pertanyaan yang dijawab oleh responden dalam kuesioner.

Tabel 1 Demografi Responden

\begin{tabular}{|l|l|r|}
\hline \multicolumn{1}{|c|}{ Demografi } & \multicolumn{1}{|c|}{ Kategori } & \multicolumn{2}{c|}{ Jumlah (\%) } \\
\hline \multirow{4}{*}{ Jenis Kelamin } & Laki-laki & $183 \quad(45,520)$ \\
\cline { 2 - 4 } & Perempuan & $219 \quad(54,48)$ \\
\hline \multirow{4}{*}{ Usia } & Remaja & $33 \quad(8,21)$ \\
\cline { 2 - 4 } & $21-25$ & $251 \quad(62,44)$ \\
\cline { 2 - 3 } & $26-40$ & $107 \quad(26,62)$ \\
\cline { 2 - 3 } & Tua & $11 \quad(2,74)$ \\
\hline Total & & $402 \quad(100,00)$ \\
\hline
\end{tabular}




\section{HASIL DAN PEMBAHASAN}

\section{Analisis Deskriptif}

Analisis deskriptif dilakukan untuk memberikan gambaran tentang data survei yang digunakan dalam penelitian ini. Temuan yang diperoleh melalui analisis deskriptif pada penelitian disajikan pada bagian berikut.

Total 402 pengguna layanan dompet digital berpartisipasi dalam penelitian ini, hasil deskriptif pada bagian ini dapat dilihat secara detail pada Tabel 1 . Tabel 1

Tabel 2 Deskriptif Variabel

\begin{tabular}{|c|c|c|c|c|c|c|c|c|c|c|c|c|c|}
\hline \multirow{3}{*}{$\begin{array}{c}\text { Fakt } \\
\text { or }\end{array}$} & \multirow{3}{*}{$\begin{array}{l}K \\
\text { et }\end{array}$} & \multicolumn{11}{|c|}{ Kategori } & \\
\hline & & & & \multicolumn{4}{|c|}{ Usia } & \multicolumn{5}{|c|}{$\begin{array}{c}\text { Dompet } \\
\text { Digital }\end{array}$} & $\begin{array}{l}\mathbf{M} \\
\mathbf{e} \\
- \\
\mathbf{a}\end{array}$ \\
\hline & & $\begin{array}{l}\mathbf{L} \\
\mathbf{K}\end{array}$ & $\begin{array}{l}\mathbf{P} \\
\mathbf{R}\end{array}$ & $\begin{array}{l}\mathbf{R} \\
\mathbf{M}\end{array}$ & $\begin{array}{l}2 \\
1 \\
- \\
5\end{array}$ & $\begin{array}{l}2 \\
6 \\
- \\
4\end{array}$ & $\begin{array}{l}\mathbf{T} \\
\mathbf{U}\end{array}$ & $\begin{array}{l}\mathbf{G} \\
\mathbf{P}\end{array}$ & $\begin{array}{l}\mathbf{O} \\
\mathbf{V}\end{array}$ & $\begin{array}{l}\mathbf{D} \\
\mathbf{N}\end{array}$ & $\begin{array}{l}\mathbf{L} \\
\mathbf{A}\end{array}$ & $\begin{array}{l}\mathbf{S} \\
\mathbf{P}\end{array}$ & $\mathbf{n}$ \\
\hline $\begin{array}{l}\text { Kegu } \\
\text { naan }\end{array}$ & $\begin{array}{l}\mathrm{M} \\
\mathrm{ea} \\
\mathrm{n}\end{array}$ & $\begin{array}{l}4 \\
, \\
1 \\
0 \\
0 \\
, \\
6 \\
9\end{array}$ & $\begin{array}{l}4 \\
, \\
1 \\
1 \\
0 \\
6 \\
7 \\
3\end{array}$ & $\begin{array}{l}3 \\
, \\
9 \\
5\end{array}$ & $\begin{array}{l}4 \\
, \\
1 \\
4 \\
0 \\
, \\
6 \\
8\end{array}$ & $\begin{array}{l}4 \\
9 \\
0 \\
8 \\
0 \\
9 \\
7 \\
6\end{array}$ & $\begin{array}{l}3 \\
9 \\
8 \\
0 \\
0 \\
9 \\
5 \\
9\end{array}$ & $\begin{array}{l}4 \\
, \\
1 \\
5 \\
0 \\
6 \\
6 \\
3\end{array}$ & $\begin{array}{l}4 \\
, \\
1 \\
3\end{array}$ & $\begin{array}{l}4 \\
, \\
1 \\
6\end{array}$ & $\begin{array}{l}4 \\
, \\
1 \\
1 \\
0 \\
, \\
6 \\
5\end{array}$ & $\begin{array}{l}3 \\
, \\
7 \\
9 \\
0 \\
9 \\
9 \\
0\end{array}$ & $\begin{array}{l}4 \\
, \\
0 \\
5\end{array}$ \\
\hline $\begin{array}{l}\text { Kem } \\
\text { udah } \\
\text { an }\end{array}$ & $\begin{array}{l}\mathrm{M} \\
\mathrm{ea} \\
\mathrm{n}\end{array}$ & $\begin{array}{l}4 \\
\text {, } \\
0 \\
3\end{array}$ & $\begin{array}{l}4 \\
, \\
0 \\
9 \\
0 \\
6 \\
7 \\
2\end{array}$ & $\begin{array}{l}0 \\
6 \\
6 \\
1\end{array}$ & $\begin{array}{l}4 \\
, \\
1 \\
2 \\
0 \\
, \\
6 \\
7\end{array}$ & $\begin{array}{c}3 \\
9 \\
9 \\
8 \\
0 \\
9 \\
8 \\
4\end{array}$ & $\begin{array}{l}3 \\
9 \\
7 \\
3 \\
0 \\
9 \\
4 \\
9\end{array}$ & $\begin{array}{l}4 \\
, \\
1 \\
1 \\
0 \\
2 \\
6 \\
5\end{array}$ & $\begin{array}{l}4 \\
9 \\
0 \\
8 \\
0 \\
9 \\
7 \\
3\end{array}$ & $\begin{array}{l}4 \\
, \\
0 \\
5\end{array}$ & $\begin{array}{l}4 \\
, \\
1 \\
2 \\
0 \\
9 \\
6 \\
9\end{array}$ & $\begin{array}{c}3 \\
, \\
8 \\
0 \\
0 \\
9 \\
9 \\
2\end{array}$ & $\begin{array}{l}4 \\
, \\
0 \\
1 \\
0 \\
, \\
7 \\
0\end{array}$ \\
\hline $\begin{array}{l}\text { Fina } \\
\text { nsial }\end{array}$ & $\begin{array}{l}\mathrm{M} \\
\text { ea } \\
\mathrm{n}\end{array}$ & $\begin{array}{l}3 \\
, \\
9 \\
3\end{array}$ & $\begin{array}{l}3 \\
\text {, } \\
9 \\
7 \\
0 \\
6 \\
7 \\
6\end{array}$ & $\begin{array}{l}3 \\
, \\
9 \\
3\end{array}$ & $\begin{array}{l}3 \\
, \\
9 \\
8 \\
0 \\
6 \\
7 \\
1\end{array}$ & $\begin{array}{l}3 \\
, \\
9 \\
4 \\
0 \\
9 \\
8 \\
2\end{array}$ & $\begin{array}{l}3 \\
, \\
5 \\
5 \\
0 \\
6 \\
6 \\
5\end{array}$ & $\begin{array}{l}3 \\
, \\
8 \\
8 \\
0 \\
7 \\
7 \\
3\end{array}$ & $\begin{array}{l}4 \\
, \\
0 \\
2\end{array}$ & $\begin{array}{l}3 \\
, \\
9 \\
5\end{array}$ & $\begin{array}{l}4 \\
2 \\
0 \\
2\end{array}$ & $\begin{array}{l}3 \\
, \\
8 \\
7 \\
0 \\
9 \\
9 \\
0\end{array}$ & $\begin{array}{l}3 \\
, \\
9 \\
1 \\
0 \\
6 \\
7 \\
8\end{array}$ \\
\hline
\end{tabular}

memberikan informasi deskriptif mengenai jumlah responden berdasarkan umur dan jenis kelamin. Pada informasi usia dibagi menjadi empat kategori, yaitu pengguna dengan usia kurang dari 21 tahun yang kemudian disebut sebagai usia remaja, usia 21 hingga 25 tahun, usia 26 hingga 40 tahun, dan usia lebih dari 40 tahun yang kemudian pada penelitian ini disebut usia tua. Separuh lebih reponden penelitian ini perempuan $(54,48 \%)$, selain itu mayoritas responden memiliki rentag usia $21-25$ tahun $(62,44 \%)$.

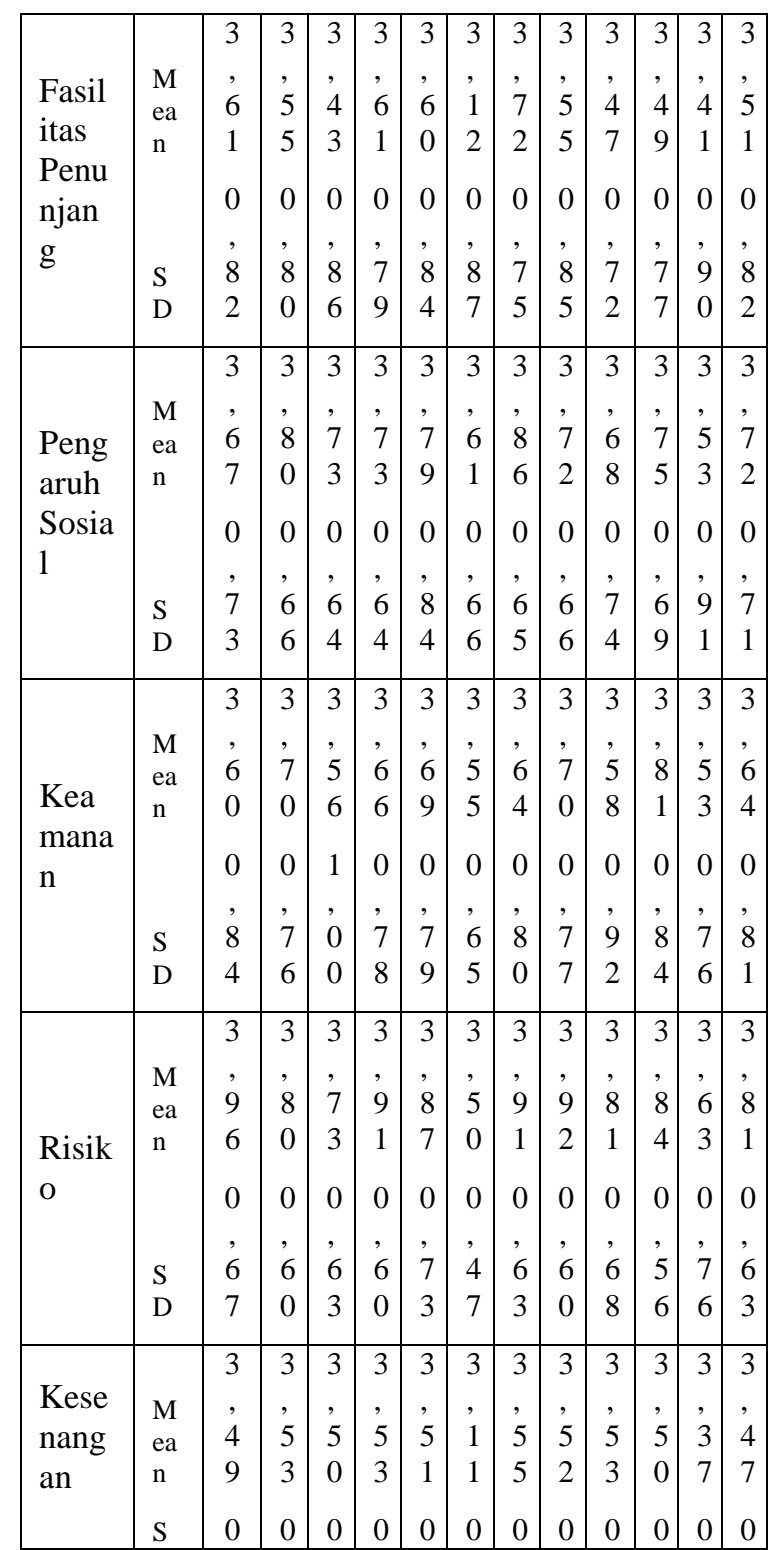




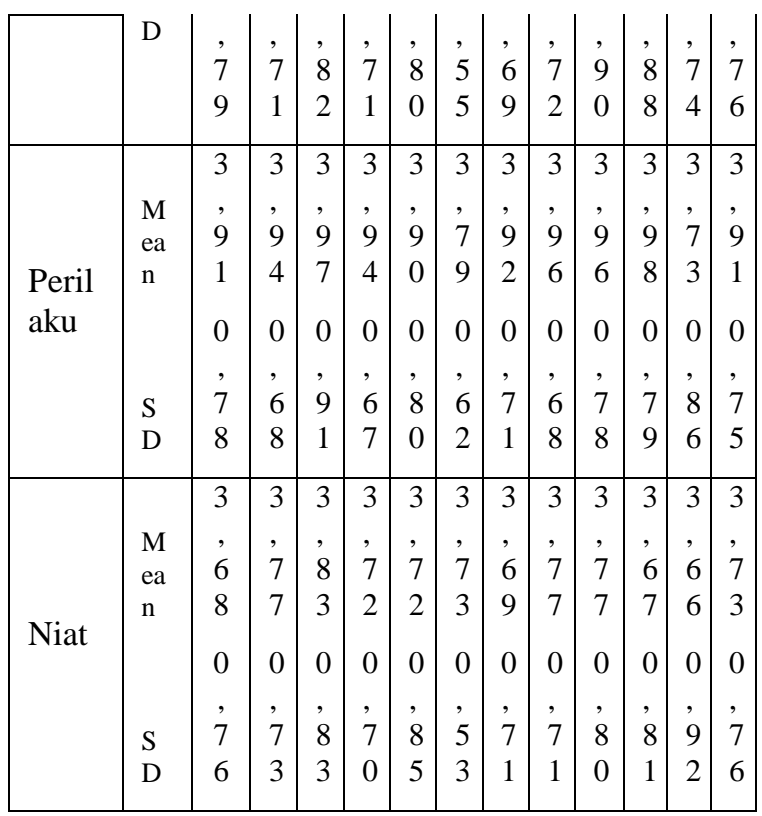

Berdasar pada kategori pada independent variables yakni kategori usia, jenis kelamin dan dompet digital, setiap kategori memiliki penilaian tertinggi pada faktor kegunaan, namun tidak dengan kategori dompet digital jenis ShopeePay yang memiliki penilaian tertinggi pada faktor finansial (mean=3,87, $\mathrm{SD}=0,90$ ). Pada kategori dompet digital LinkAja, penilaian tertinggi yakni 5 sering diberikan oleh responden pada faktor finansial. Selain itu, dompet digital OVO juga sering mendapatkan penilaian 5 pada faktor kegunaan. Berdasarkan pada dependant variables atau faktor-faktor yang diteliti, faktor kegunaan memiliki rata-rata penilaian yang paling baik diantara faktor yang lain (mean $=4,05$, $\mathrm{SD}=0,71$ ), sedangkan faktor dengan ratarata penilaian terendah adalah faktor fasilitas penunjang (mean=3,51, $\mathrm{SD}=0,82$. Faktor kemudahan dan faktor perilaku, paling sering mendapatkan penilaian 4 dari responden. Informasi lebih lanjut dapat dilihat pada Tabel 2.

\section{Pengguna Layanan Dompet Digital}

Penelitian ini mengumpulkan data pengguna layanan dompet digital yang paling sering digunakan, sehingga setiap responden hanya dapet memilih satu layanan dompet digital. Hasil pengumpulan data sampel menemukan bahwa hampir setengah dari responden penelitian merupakan pengguna layanan OVO (40,80\%), disusul oleh pengguna layanan GoPay $(31,84 \%)$, layanan dompet digital Dana (10,95\%), layanan dompet digital ShopeePay $(9,70 \%)$, dan yang terakhir layanan dompet digital LinkAja $(6,72 \%)$. Jika responden dibandingkan disetiap layanan dompet digital, mayoritas didominasi oleh pengguna perempuan, kecuali layanan dompet digital Dana yang mayoritas penggunanya merupakan lakilaki. Adapun informasi secara detail dapat dilihat pada Tabel 3.

Tabel 3 Pengguna Layanan Dompet Digital

\begin{tabular}{|c|c|c|c|c|c|c|}
\hline \multirow{2}{*}{ Usia } & \multirow{2}{*}{ Jenis Kelamin } & \multicolumn{5}{|c|}{ Jenis Layanan Dompet Digital } \\
\hline & & GoPay (\%) & OVO (\%) & Dana $(\%)$ & LinkAja (\%) & ShopeePay (\%) \\
\hline \multirow{2}{*}{ Remaja } & Laki-laki & $\begin{array}{ll}3 & (0,75)\end{array}$ & $6 \quad(1,49)$ & $4 \quad(1,00)$ & $\begin{array}{ll}0 & (0,00)\end{array}$ & $\begin{array}{ll}0 & (0,00)\end{array}$ \\
\hline & Perempuan & $3 \quad(0,75)$ & $9 \quad(2,24)$ & $3 \quad(0,75)$ & $2 \quad(0,50)$ & $3(0,75)$ \\
\hline \multirow{2}{*}{$21-25$} & Laki-laki & $33 \quad(8,21)$ & $46 \quad(11,44)$ & $\begin{array}{ll}17 \quad(4,23) \\
\end{array}$ & $\begin{array}{ll}6 & (1,49)\end{array}$ & $\begin{array}{ll}6 & (1,49)\end{array}$ \\
\hline & Perempuan & $48 \quad(11,94)$ & $62 \quad(15,42)$ & $10 \quad(2,49)$ & $9 \quad(2,24)$ & $14 \quad(3,48)$ \\
\hline \multirow{2}{*}{$26-40$} & Laki-laki & $18 \quad(4,48)$ & $18 \quad(4,48)$ & $8 \quad(1,99)$ & $5 \quad(1,24)$ & $8 \quad(1,99)$ \\
\hline & Perempuan & $18 \quad(4,48)$ & $21 \quad(5,22)$ & $1 \quad(0,25)$ & $4 \quad(1,00)$ & $6 \quad(1,49)$ \\
\hline Tua & Laki-laki & $2 \quad(0,50)$ & $1 \quad(0,25)$ & $\begin{array}{ll}0 & (0,00)\end{array}$ & $1 \quad(0,25)$ & $\begin{array}{ll}1 & (0,25)\end{array}$ \\
\hline
\end{tabular}




\begin{tabular}{|l|r|rr|rr|rr|rr|r|r|}
\hline & Perempuan & 3 & $(0,75)$ & 1 & $(0,25)$ & 1 & $(0,25)$ & 0 & $(0,00)$ & 1 & $(0,25)$ \\
\hline \multirow{2}{*}{ Total } & 128 & $(31,84)$ & 164 & $(40,80)$ & 44 & $(10,95)$ & 27 & $(6,72)$ & 39 & $(9,70)$ \\
\cline { 2 - 8 } & \multicolumn{8}{|c|}{$402(100,00 \%)$} \\
\hline
\end{tabular}

Perbandingan Sikap Pengguna

Data yang telah terkumpul dianalisis dengan metode Manova. Analisis Manova memperlihatkan perbandingkan dampak dari tingkat yang berbeda dari variabel kategorikal pada variabel kuantitatif. Hasil menunjukkan bahwa dari sepuluh faktor yang diteliti, tidak terdapat perbedaan yang signifikan terhadap jenis dompet digital apa yang digunakan, sehingga dapat dikatakan bahwa menggunakan dompet digital apapun tidak begitu penting. Hal demikian juga terjadi pada usia, karena tidak terdapat signifikansi pada independent variable ini. Namun berbeda dengan jenis kelamin, karena terdapat dua faktor yang signifikan berpengaruh. Jenis kelamin terbukti signifikan pada faktor pengaruh sosial lingkungan sekitar dan faktor risiko $(\operatorname{Pr}<0,01)$. Hasil analisis Manova lebih lengkap dapat dilihat pada Tabel 4.

Tabel 4 Hasil Analisi Manova

\begin{tabular}{|l|c|c|c|c|c|c|}
\hline \multirow{2}{*}{ Faktor } & \multicolumn{2}{|c|}{ Dompet Digital } & \multicolumn{2}{c|}{ Usia } & \multicolumn{2}{c|}{ Jenis Kelamin } \\
\cline { 2 - 7 } & Value & $\operatorname{Pr}(>\mathbf{F})$ & Value & $\operatorname{Pr}(>\mathbf{F})$ & Value & $\operatorname{Pr}(>\mathbf{F})$ \\
\hline Kegunaan & 2,205 & 0,068 & 0,756 & 0,520 & 0,114 & 0,736 \\
\hline Kemudahan & 1,493 & 0,204 & 1,701 & 0,166 & 0,448 & 0,504 \\
\hline Finansial & 0,787 & 0,534 & 1,010 & 0,388 & 0,414 & 0,520 \\
\hline Fasilitas penunjang & 1,799 & 0,128 & 1,593 & 0,128 & 0,618 & 0,432 \\
\hline Pengaruh sosial & 2,013 & 0,092 & 0,390 & 0,760 & 4,091 & 0,044 \\
\hline Kemanan & 0,749 & 0,559 & 0,284 & 0,837 & 1,692 & 0,194 \\
\hline Risiko & 1,878 & 0,114 & 1,799 & 0,147 & 6,028 & 0,015 \\
\hline Kesenangan & 0,489 & 0,744 & 1,073 & 0,360 & 0,413 & 0,521 \\
\hline Perilaku & 0,862 & 0,487 & 0,142 & 0,935 & 0,255 & 0,614 \\
\hline Niat & 0,405 & 0,805 & 0,171 & 0,916 & 1,291 & 0,257 \\
\hline
\end{tabular}

Gambar 1 merupakan boxplot dari variabel jenis kelamin pada faktor pengaruh sosial lingkungan sekitar dari responden. Boxplot pada perempuan memiliki maximum potential outlier hingga nilai 5. Minimum outliers pada perempuan lebih tinggi jika dibandingkan dengan laki-laki, yakni pada nilai 2,5. Laki-laki dan perempuan memiliki nilai
$\mathrm{Q}_{3}$ yang sama, yakni pada nilai 4 dan $\mathrm{Q}_{2}$ pada nilai 3,75. Namun keduanya memiliki $\mathrm{Q}_{1}$ yang berbeda (laki-laki=3,25 dan perempuan $=3,50$ ). 


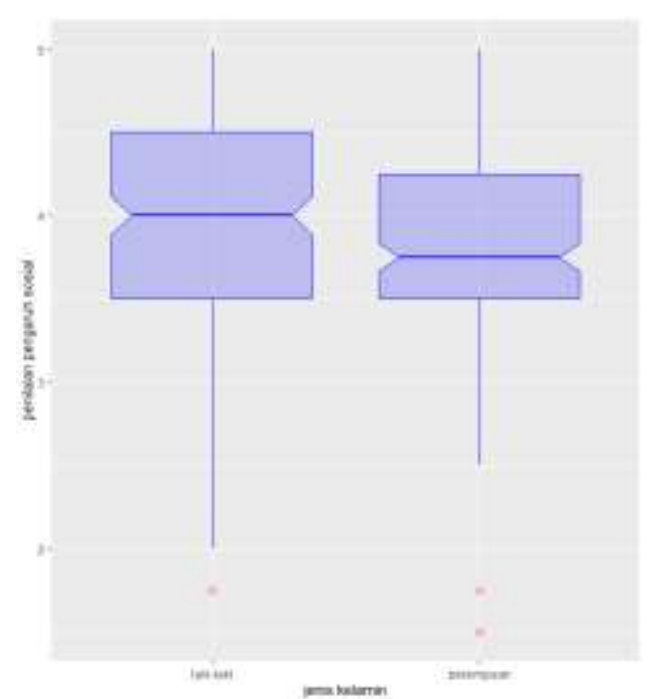

Gambar 1 Variabel Jenis Kelamin pada Faktor Pengaruh Sosial

Sedangkan faktor risiko ditunjukkan pada Gambar 2. Baik pada perempuan maupun laki-laki tidak memiliki maximum potential outliers, namun memiliki minimum potential outliers (laki-laki=1,75 dan perempuan=1,50 hingga 1,75). Pada faktor risiko, laki-laki dan perempuan memiliki persamaan $\mathrm{Q}_{1}$, yakni pada nilai 3,50 dan maximum data pada nilai 5 .

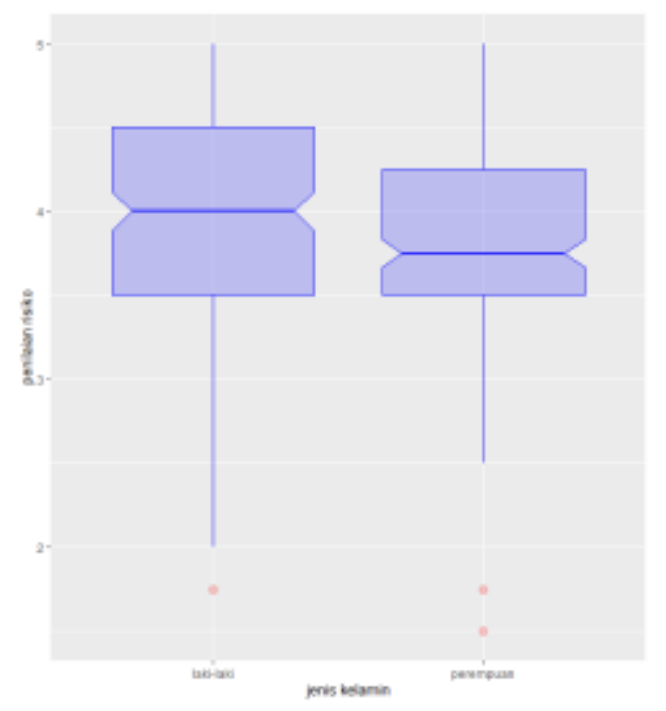

Gambar 2 Variabel Jenis Kelamin pada Faktor Risiko

\section{SIMPULAN}

Temuan dari hasil analisis di studi ini menunjukkan relatif tidak ada perbedaanperbedaan dari sisi faktor-faktor penerimaan dompet digital antar jenis layanan dompet digital, usia dan jenis kelamin kecuali pada dua hal. Hal yang pertama yaitu pada faktor pengaruh sosial di mana perempuan melaporkan nilai yang lebih tinggi dibandingkan laki-laki. Hal ini mengindikasikan bahwa perempuan pengguna layanan dompet digital besar kemungkinan telah dipengaruhi oleh lingkungan sekitarnya yang menggunakan layanan dompet digital. Hal kedua, yakni pada persepsi risiko yang justru sebaliknya, bahwa laki-laki melaporkan nilai yang lebih tinggi daripada perempuan. Hal ini menunjukkan bahwa laki-laki menilai risiko ketika menggunakan layanan dompet digital lebih besar dibandingkan dengan perempuan.

Temuan dari penelitian ini dapat melengkapi dan memperkaya literatur di bidang teknologi finansial dan memberikan gambaran perbandingan atau perbedaan sikap dari pengguna layanan dompet digital di Indonesia. Selain itu, pengetahuan dari penelitian ini tidak hanya bermanfaat bagi penyedia layanan dompet digital, namun secara luas bagi industri teknologi finasial. Salah satu kekurangan penelitian dalam penyebaran usia yang kurang merata disetiap kategorinya. Untuk pengembangan penelitian selanjutnya dapat diteliti dengan menambah atau mengubah variabel usia dan jenis kelamin, dengan variabel asal daerah, jenjang pendidikan dan pekerjaan sehingga dapat lebih lengkap dalam memberikan gambaran perbandingan atau perbedaan sikap dari pengguna layanan dompet digital. 


\section{DAFTAR PUSTAKA}

[1] Tazkiyyaturrohmah, R., 2018, Eksistensi Uang Elektronik Sebagai Alat Transaksi Keuangan Modern, Muslim Heritage, Vol 3, No 1, Hal 23-44.

[2] Roy, S., \& Sinha, I., 2014, Determinants of Customers' Acceptance of Electronic Payment System in Indian Banking Sector - A Study, International Journal of Scientific \& Engineering Research, Vol 5, Issue 1, Hal 177-187.

[3] Koponen, A., 2006, E-Commerce, Electronic Payments, Innovation in Telecommunications Helsinki University of Technology, Telecommunications Software and Multimedia Laboratory, Hal 26-30.

[4] Junadi, \& Sfenrianto, 2015, A Model of Factors Influencing Consumer's Intention to Use, Procedia Computer Sciece, Vol 59, No 1, Hal 214-220.

[5] Angelina C and Rahadi R A 2020 A conceptual study on the factors influencing usage intention of ewallet in Java, Indonesia IJAFB 5(27) pp 19-29.

[6] Tempo.co, 2021, Persaingan 5 Dompet Digital Berebut Pasar di Masa Pandemi Covid-19, diakses 27 Mei 2021 di https://bisnis.tempo.co/read/1445184/ persaingan-5-dompet-digital-berebutpasar-di-masa-pandemi-covid-19.

[7] IPSOS, 2020, Evolusi Industri Dompet Digital Strategi Menang Tanpa Bakar Uang, diakses 21 Mei 2021

https://www.ipsos.com/sites/default/fi les/ct/news/documents/2020-

02/ipsos_-_press_release_indonesian.pdf.

[8] Tarantang, J., Awwaliyah, A., Astuti, M., \& Munawaroh, M., 2019, Perkembangan Sistem Pembayaran Digital Pada Era Revolusi Industri 4.0 di Indonesia, Jurnal Al Qardh, Vol 4, Hal 60-75.

[9] Raihan, T., \& Rachmawati, I., 2019, Analyzing Factors Influencing Continuance Intention of E-wallet Adoption Using UTAUT 2 Model (A ACase Study of Dana Indonesia). $e$ Proceeding of Management. Vol 6, No 2, Hal 1-8.

[10] Widiyanti, W., 2020, Pengaruh Kemanfaatan, Kemudahan Penggunaan dan Promosi Terhadap Keputusan Penggunaan E-wallet OVO di Depok. Moneter: Jurnal Akuntansi dan Keuangan, Hal 54-63.

[11] Saputri, A. D., \& Pratama, A. R., 2021, Identifying User Characteristics of the Top Three E-Wallet Services in Indonesia, IOP Conference Series: Materials Science and Engineering, Vol 1077, No 1, Hal 1-11.

[12] Juniarti, R. P., 2018, Faktor-Faktor yang Memengaruhi Penggunaan Mobile Payment: Sebuah Review Literature, Sinergitas Quadruple Helix: e-Business dan Fintech sebagai Daya Dorong Pertumbuhan Ekonomi Lokal, hal 526-534.

[13] Ghozali, I., 2006, Aplikasi Analisis Multivariate dengan Program SPSS. Badan Penerbit Universitas Diponegoro. 